\title{
Composition of reef fish as a success indicator of the bio-transplants method in Tunda Island, Serang Regency, Banten Province
}

\author{
Mujiyanto $^{1 *}$, A. R. Syam ${ }^{1}$, and Adriani. S. Nastiti ${ }^{1}$ \\ ${ }^{1}$ Research Institute for Fisheries Resources Enhancement, Ministry of Marine Affairs and Fisheries, Jl. \\ Cilalawi No. 01 Jatiluhur, Purwakarta, West Java 41152 - Republic of Indonesia
}

\begin{abstract}
The Bio-Transplants method is a coral grafting method by inoculating coral seedlings/fragments using natural materials. They are dead corals in the DC and DCA categories as a place of attachment. This study aims to see the success of the Bio-Transplants method in compiling indicators of fish species associated with the field of Bio-Transplants. They have conducted this research in $10 \times 10$ square meters on the north side of Tunda Island waters in July $2019\left(\mathrm{~T}_{0}\right)$, November $2019\left(\mathrm{~T}_{1}\right)$, and July 2020 $\left(\mathrm{T}_{2}\right)$. The sampling method used a stationary visual census. In July 2019 , as many as 11 species from 7 families, November 2019 was 31 species from 10 families, and July 2020 was 47 species from 10 families. Composition of fish species as an indicator of the health of coral ecosystems from the Chaetodontidae family fish species. In July, when Bio-Transplants started production, there were no fish groups from the Chaetodontidae family. The composition of the fish species found in November was Chelmon sp. and Henichus varius. After its age, the Bio Transplants area was one year (July 2020) consisting of 4 fish species from the family Chaetodontidae, namely: Heniochus chrysostomus, Chaetodon trifasciatus, Chelmon sp., and Heniochus varius.
\end{abstract}

\section{Introduction}

The presence of reef fish, both in quantity and quality, is closely related to the health status of coral reefs, as evidenced by the percentage of living coral cover according to [1]. It is also the type of diversity in the coral reef ecosystem. The interaction among reef fish and coral reefs as their habitat can be divided into three forms, as follows: (1) direct interaction as shelter from predators, especially juvenile fish; (2) feeding habits and predator-prey interactions, including the relationship among reef fish and biota living on corals, including algae; and (3) indirect interactions due to coral structure and hydrological and sedimentary conditions according to [2].

Efforts to maintain the coral reef ecosystem's stability are generally made in zoning in protected areas, but efforts to restore coral habitats rely on natural restoration take a long time. Some form of action is required to improve coral reef ecosystems, such as habitat

\footnotetext{
*Corresponding author : antomj18@gmail.com
} 
restoration. The restoration of the coral habitat will be expected to provide ecosystem stability for the biota community within it. Reef rehabilitation is a part of fisheries technology innovation that focuses on coral restoration or repair to coral reef ecosystem stability. Why is reef habitat rehabilitation done? According to data from [3], out of a total of 1067 sites, poor category reefs are 386 sites $(36.18 \%)$, fair category reefs are 366 sites $(34.3 \%)$, good category reefs are 245 sites ( $22.96 \%)$, and excellent categories are 70 sites $(6.56 \%)$. The rehabilitation technology in question is active biological recovery, which uses massive coral species categorized as DC and DCA as coral transplantation media. Took the development of the rehabilitation model from the concept of [4], namely by collecting corals directly from the reef and transplanting them into damaged areas. The product in question will make a model with stratification to see the difference in growth.

The technique of attaching fragments to the planned natural substrate was performed as follows [4]: a) Search for natural holes with the same diameter as the fragments; b) Make a hole in the reef with a chisel or screwdriver, depending on the size, and c) Glue the reef fragments to the holes provided (provided) using a paste adhesive on one side, and the other side with the coral fragments pressed down until they touch the bottom of the holes on the substrate. Using natural substrates in the DC and DCA categories by perforating the surface for the attachment of fragments is called the Bio-Transplant Method.

Biota that is interacted most closely with objects placed on the bottom of the water are fish, so the indicators used to determine the success and failure of the Bio-transplant method. $[5,6]$ found a positive correlation between live coral and the abundance of fish and the diversity of butterflyfish of the family in Polynesian coral reefs Chaetodontidae. Similarly, [7] found the same in the Flores Sea. Their study explained that the higher the living coral cover, the greater the number and abundance of butterflyfish in the coral reef. Based on various descriptions of previous research results, this study aims to determine the success rate of coral habitats rehabilitation using the Bio-Transplants method with indicators of the presence of reef fish species based on their function.

\section{Materials and methods}

\subsection{Time and location}

The research did in July 2019, November 2019, and July 2020 in the field of Bio-Transplants. The surface of Bio-Transplants is $10 \times 10$ meters, with a depth at low tide of \pm 55 meters; at high tide, its depth is \pm 125 meters. The Bio-Transplants method is a method of reef transplantation using natural materials. The raw materials are coral reef in DC and DCA categories (adhesive substrates following by Patent's Document No. S00201908839) according to [8]. Therefore, the transplantation activities use natural materials, namely coral species in the DC (Dead Coral) and DCA (Dead Coral with Algae) categories. Then holes are made on the surface of the dead coral using a manual drill for the media for fixing the fragments attached with glue and or using wooden clips to place them on the substrate. It can see details of the location and area of bio-transplants in Fig. 1 and Fig. 2. 

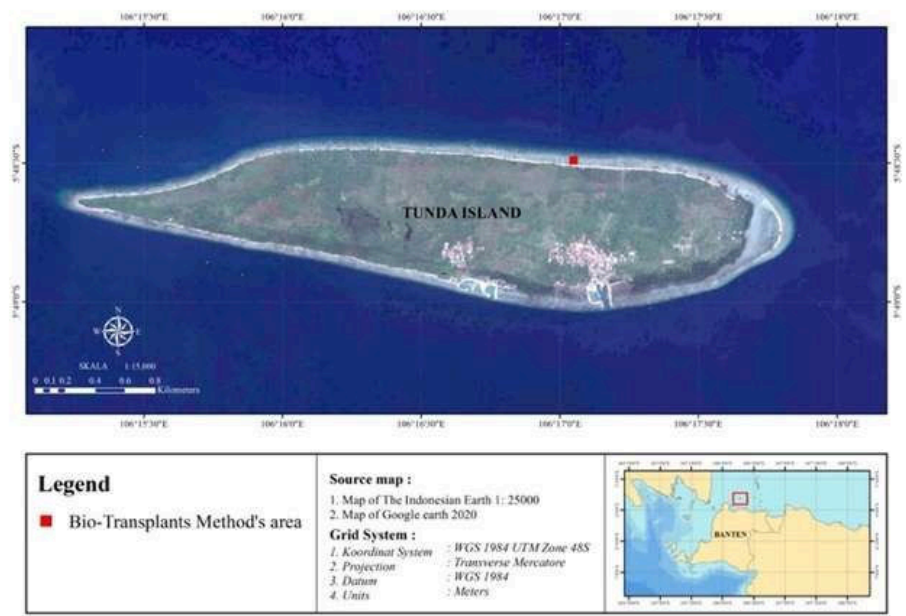

Fig. 1. Research locations in north side of Tunda Island Serang Regency, Banten Province.

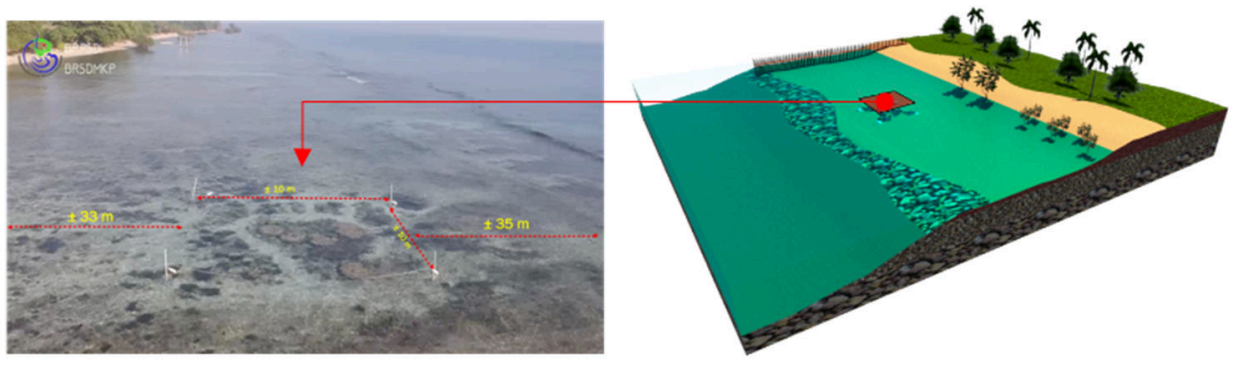

Fig. 2. Bio-Transplants Method area on intertidal waters, north side of Tunda Island.

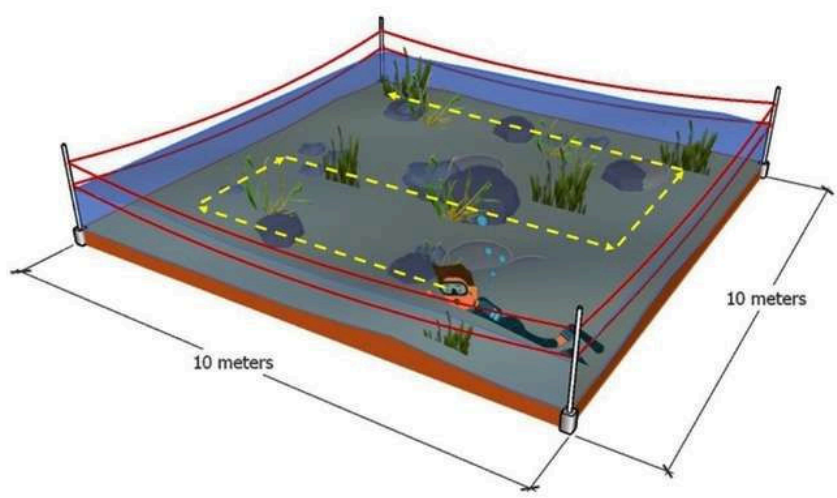

Fig. 3. The illustration of the Underwater Visual Census (UVC) Method.

The reef fish data collection uses the Underwater Visual Census (UVC) method according to [9] and [10]. First, count the number of reef fish in an area of 10x10 meters so that the analysis of the resulting data will obtain the same divisor value between observations (Fig. $3)$. Identification of reef fish species refers to $[11,12,13,14]$. The registered fish species were grouped into three main groups according to [9]: 1) target fish group, 2) indicator fish, and 3 ) major fish group. The abundance of reef fish species was calculated in individual $/$ meter $^{2}$. The target fish groups are economically important fish, and they are usually caught for 
consumption. Typically, these fish use coral reefs as spawning and nursery areas. The indicator fish group is a type of reef fish that usually inhabits coral reef areas and is an indicator of the fertility of the area's ecosystem. While the significant fish group is a type of small fish, usually $5-25 \mathrm{~cm}$, with different color characteristics known as ornamental fish, this group is generally found in abundance, both in number and in species, and tends to be territorial.

\subsection{Data analysis}

Their composition and abundance analyzed the result of reef fish identification data. Knew the species abundance (individual $/ \mathrm{m}^{2}$ ) by dividing individuals in the observation area by the observed area $\left(100 \mathrm{~m}^{2}\right)$. Meanwhile, the composition of reef fish is known by counting and classifying fish according to their sex and family, and then grouping them according to their role in the coral reef ecosystem: target fish, indicator fish, and significant fish according to $[9,15,16]$. Analysis of fish species similarity based on reef fish families found between July 2019 as $\mathrm{T}_{0}$, November 2019 as $\mathrm{T}_{1}$, and July 2020 as $\mathrm{T}_{2}$ using Principal Component Analysis (PCA). The advantage of using PCA is that it can simplify data and classify it faster, according to $[17,18]$. The statistical analysis used the XLStat 2014 software.

\section{Results}

\subsection{Fish composition per group}

Observations on the composition of reef fish species in the Bio-Transplants area found 56 species from 10 families. The composition of the fish species found is grouped into three groups based on their function. The target fish group encountered 20 species from 4 species, the indicator fish group found four species from the family Chaetodontidae, and the major fish group found 32 species from 5 families (Appendix 1). Groups of each species are described in Fig. 4, Fig. 5, and Fig. 6. Species composition before implementing the BioTransplants method in July 2019 as $\mathrm{T}_{0}$ species composition of fish in the Bio-Transplant method area no less than three species from 2 families (Fig. 4). The fish species found before the tests were Thalassoma amblycephalum and Thalassoma lunare from the family Labridae. They are inside in fish target group. The highest abundance of reef fish in July 2019 was 0.05 ind. $/ \mathrm{m}^{2}$, from Neoglyphidodon carlsoni and Thalassoma lunare species.

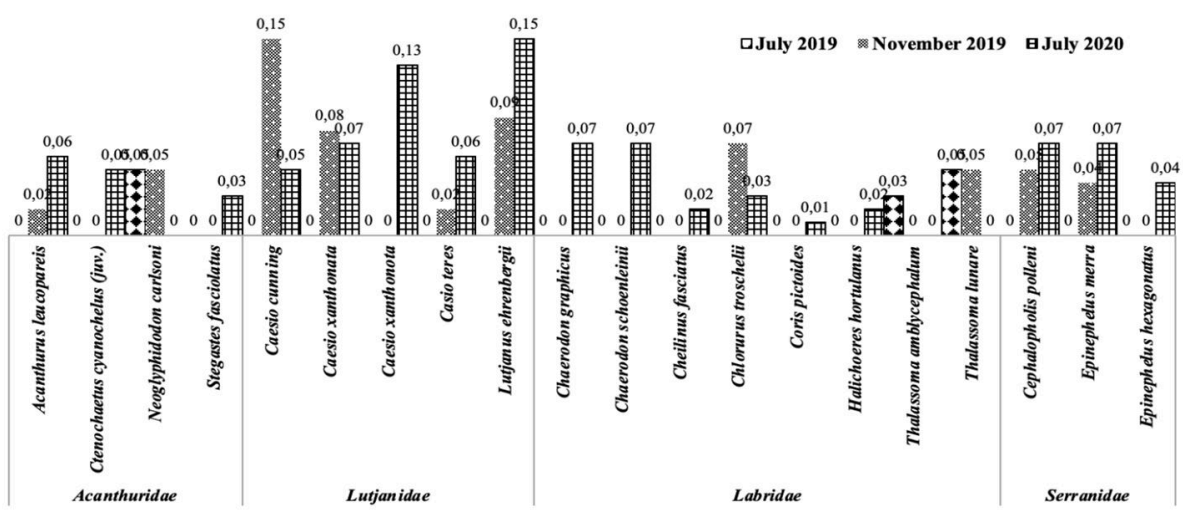

Fig. 4. The composition of the fish target group in the Bio-Transplants Area. 
The composition of the fish target species in November 2019 as $\mathrm{T}_{1}$ found ten species from 4 families, while in July 2020 as $\mathrm{T}_{2}$ found 17 species of reef fish from 4 families. The fish species composition between $\mathrm{T} 1$ and $\mathrm{T} 2$ differed in the number of species found, while the number of families was still the same, namely four species (Acanthuridae, Lutjanidae, Labridae, and Serranidae).

The reef fish species observed three times (July 2019, November 2019, and July 2020) were only from the family Chaetodontidae. The visible difference is in the number and composition of the species, with the reef fish found in July 2019 Chelmon sp. and Heniochus varius with only 0.01 ind. $/ \mathrm{m}^{2}$ each. The species was discovered during observation before testing the Bio-Transplants method. Bio-transplantation area at the age of \pm four months three species found with an abundance of fish species Chaetodon trifasciatus, Chelmon sp. and Heniochus varius no less than 0.02 ind. $/ \mathrm{m}^{2}$. Observations in July 2020 or the age of BioTransplants method \pm 12 months the number of species did not differ much, but the number of events was higher than in July 2019 and November 2019. Species composition of reef fish from the found indicator fish group at the Bio-Transplants method \pm 12 months or one year are Heniochus chrysostomus, Chaetodon trifasciatus, Chelmon sp. and Heniochus varius. The highest abundance of the four species was Heniochus varius with 0.12 ind.$/ \mathrm{m}^{2}$. Details of the abundance distribution of indicator fish in the Bio-Transplants area are described in Fig. 5.

๑Juli $2019 \square$ November 2019 口Juli 2020

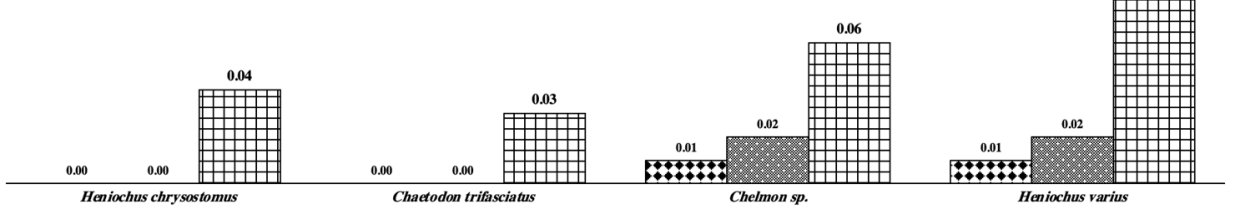

Fig. 5. The composition of the fish indicator group in Bio-Transplants Area.

The composition of reef fish species included in large fish groups during three observations (July 2019, November 2019, and July 2020) in 2019 no less than six species from the family: Pomacentridae, Scaridae, Apogonidae, and Blenniidae. The second observation in November 2019 as $\mathrm{T}_{1}$ found 19 species from 5 families, namely: Pomacentridae, Scaridae, Apogonidae, Blenniidae, and Nemipteridae, while in November 2019, the number of families found was the same as in July 2019 were four families. The differences in composition and abundance values of reef fish in the Bio-Transplants area are described in Fig. 6.

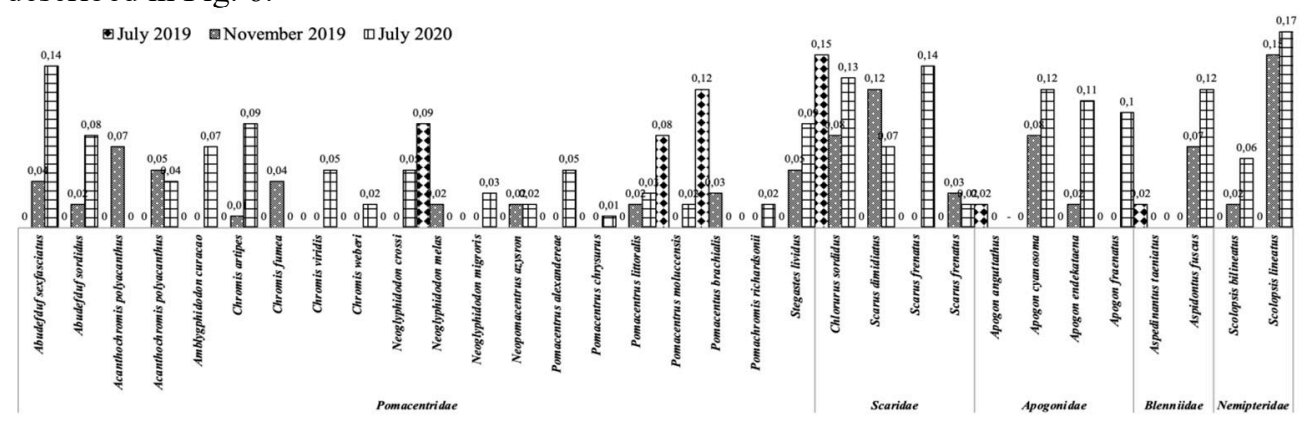

Fig. 6. The composition of the major fish group in the Bio-Transplants Area. 
The abundance of reef fish species from the main fish groups in the Bio-Transplants area in July (before the Bio-Transplants Method test) the highest abundance found was Chlorurus sordidus $\left(0.15\right.$ ind. $\left./ \mathrm{m}^{2}\right)$. The highest abundance at the 4-month Bio-Transplants area was Scolopsis lineatus $\left(0.15 \mathrm{ind} / \mathrm{m}^{2}\right)$. In comparison, in July 2020 the highest abundance species Scolopsis lineatus $\left(0.17 \mathrm{ind} / \mathrm{m}^{2}\right)$, Scarus frenatus $\left(0.14 \mathrm{ind} . / \mathrm{m}^{2}\right)$, and Abudefduf sexfasciatus $\left(0.14\right.$ ind. $\left./ \mathrm{m}^{2}\right)$.

\subsection{Fish species resemblance based on the family over time}

The results of the analysis of the degree of similarity in the number of reef fish species based on family groups of 3 times observation (July 2019, November 2019, and July 2020) as $\mathrm{T}_{0}$, $\mathrm{T}_{1}$, and $\mathrm{T}_{2}$ resulted in the composition of the similarity group of 2 groups of biplot axles with a $96.75 \%$ confidence level. The first group is the families Scaridae and Pomacentirdae, showing a trend in the number of species in July 2019. The group with the same number of reef fish species was in July 2020 and November 2019 with the same species from the family Lutjanidae. Found the similarity of fish species in the family category during the observation is from Lutjanidae. It will be present in the coral ecosystem at the age of more than four months, while groups of Pomacentridae and Scaridae tend to be present at the period of more than four months and are also found at the age of more than four months. But from Fig. 7, it is explained that the most significant presence in fish species from the family Lutjanidae.

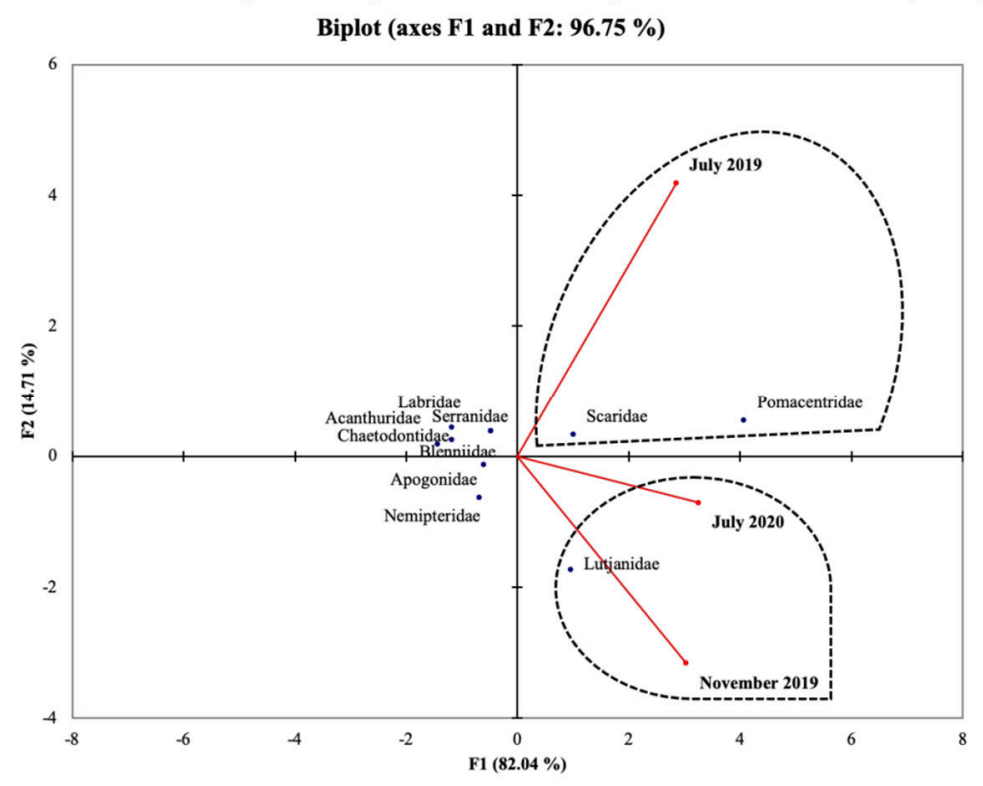

Fig. 7. The similarity of fish species based on reef fish families between observation times.

\section{Discussion}

\subsection{Fish composition per group}

Found reef fish species fall into indicator fish groups of as many as 32 species from 5 families. In comparison, the reef fish composition enters into the target category fish group's as many as 20 species from 4 reef fish families - the family of target category from Acanthuridae, Lutjanidae, Labridae, and Serranidae families of reef fishes. The three's reef 
fishes families classified are highest in reef waters. [19] found target fish families with high species composition, namely Labridae (37), Acanthuridae (13), Serranidae (12), Scaridae (10), Nemipteridae (9), Apogonidae (7), Siganidae (7), and Casionidae (5) during research in Kendari coastal water Southeast Sulawesi, except families belonging to the main species group.

The target fish's highest abundance values observed in July 2019, November 2019, and July 2020 were Caesio cuning and Lutjanus ehrenbergii, no less than 0.15 ind. $/ \mathrm{m}^{2}$. [19] also explained in their study that the target fish population in Kendari's coastal waters was dominated by yellowtail fish (Caesio cuning, a whopping 5.64\%). The distribution was almost evenly distributed across all study sites. Most yellowtail fish are still in the juvenile stage, these fish usually live in colonies (schooling), and the chicks are found in coral areas in the bay waters. The four families of reef fish were found during three observations. The family Lutjanidae is the family with the most considerable amount of reef fish species. The species of Caesio cuning is a type of reef fish that is the target of catch in the waters of the Thousand Islands. [20] explained that the condition of the coral reef ecosystem in the Thousand Islands has declined, with a hard coral cover percentage of $33.2 \%$ in 2005 (moderate category). Most of the damage to coral reefs results from human activities, including destructive and excessive fishing, according to [21]. The study by [22] in the waters of the island of Halang Melingkau, South Kalimantan, also showed that the highest number of species found in this study was Caesio cuning (family Caesionidae), with a total of 493 individuals.

The difference of reef fish species composition between $T_{0}$ and $T_{2}$ is the number of species present, wherein in July 2019, there were six species $\left(\mathrm{T}_{0}\right)$, while at 12 months BioTransplants $\left(\mathrm{T}_{2}\right), 26$ species of reef fish were found from 4 families. The four families found at 12 months of age were Pomacentridae, Scaridae, Apogonidae, and Nemipteridae. The Pomacentridae and Labridae families are part of the large fish group that consistently dominates the waters of Halang Melingkau Island. In addition, the families Pomacentridae and Labridae live their entire lives on coral reefs, according to [9].

The abundance of reef fish aged one year and older looks varied in the Bio-Transplants area. It can see the distribution of abundance between species from each central group family in Fig. 6. The Pomacentridae family is widely distributed in the Indo-Pacific region, according to [23, 22]. [24] discussed Families Pomacentridae and Labridae also dominate the marine fish fauna of the Redang Islands, Malaysia. According to [25], the frequency of occurrence of positive and negative relationships between 1) Hard coral and abundance of fish species from the family Pomacentridae is known as prey for trout; 2) Hard coral and abundance of planktivores; 3) Hard coral cover and benthic planktivore abundance; 4) Hard coral cover and trout abundance, and 5) Trout abundance and abundance of damselfly planktivorous prey.

\subsection{Fish species resemblance based on the family over time}

Fish species that dominated and were strongly present at four months and 12 months of age were Caesio cuning (15 fish individuals), Lutjanus ehrenbergii (15 fish individuals), and Caesio xanthonota (13 fish individuals). This condition illustrates that the existence of the Bio-Transplants area can offer a place as a nursery and breeding ground. During the observation, the size of the fish species is classified as juveniles. There were no fish species $>30 \mathrm{~cm}$ in size. It is suspected that the Bio-Transplants area is a nursery because it lies at a depth of 75-125 meters (intertidal zone). After the fish reach the adult stage, they migrate to deeper waters. The interaction between time and the increase in fragment colonies would create a new habitat for fish stocks in the Bio-Transplants area. According to by $[2,26,21]$ explained that the interaction among fish and reef habits could be divided into three forms, 
as follows: (1) direct interaction as shelter from predators, especially for juvenile fish; (2) feeding habit interactions, including the relationship between reef fish and biota living on corals, including algae; and (3) indirect interactions due to coral structure and hydrological and sedimentary conditions.

In addition, the family Chaetodontidae, viewed from the highest number of similarity groups, was not included in the fish species that dominated during the three-time of observations. Still, fish species from the family Chateodontidae provided an overview of environmental health in the Bio - Transplantation area. The fish species found were Chelmon sp. $\left(\mathrm{T}_{0}=1\right.$ individual; $\mathrm{T}_{1}=2$ individuals and $\mathrm{T}_{2}=6$ individuals $)$ and Heniochus varius $\left(\mathrm{T}_{0}=1\right.$ individual; $\mathrm{T}_{1}=2$ individuals and $\mathrm{T}_{2}=12$ individuals). Although not included in the dominant group for three observations, this condition may provide an overview of environmental health changes in the bio-transplant area in a suitable category. It may give a new intertidal ecosystem as a nursery and feeding ground. The Chaetodontidae family are actual coral reef fish. Distribution is limited to coral reef ecosystems due to reliance on coral reefs as a food source, according to [27]. However, not all Chaetodontidae fish consume coral polyps as to their staple diet. The presence and abundance of the Chaetodontidae family in the waters can provide an overview of the condition of local coral reefs, according to [22].

\section{Conclusions}

a. The composition of reef fish species in the Bio-Transplants area was found as 56 species from 10 families. The composition of the found fish species was grouped into three groups according to their function, the target fish group found 20 species from 4 families, the indicator fish group found four species from the family Chaetodontidae. The major fish group encountered 32 species from 5 families.

b. Fish species that dominated and were strongly present at four months and 12 months of age were Caesio cuning (15 individuals), Lutjanus ehrenbergii (15 individuals), and Caesio xanthonota (13 individuals). This condition illustrates that the existence of the Bio-Transplants area can offer a place as a nursery and breeding ground.

c. The indicator fish species indicate the environmental suitability of the Bio-Transplants area to illustrate the stability of the fish's living environment. After age 1 year (July 2020), the Bio-Transplants area consists of 4 fish species from the family Chaetodontidae: Heniochusc hrysostomus, Chaetodon trifasciatus, Chelmon sp., and Heniochus varius.

d. Coral rehabilitation doesn't just happen at the bottom of the water. Coral recovery should focus on the fish life cycle to experience migration from estuarine waters and intertidal areas to deep waters.

\section{Acknowledgements}

The author would like to thank the head of the Research Institute for Fisheries Enhancement for the permission given during the research at Tunda Island, Serang Regency, Banten Province. The data and information contained in this study are part of a research activity entitled "Research on the rehabilitation of coral reefs on the Banten Coast," which was conducted in the waters of Tunda Island, Serang Regency, in 2019-2020. The authors would like to field team and monthly data enumerator team (Mr. Rahmatullah and Mr. Umarudin) who carried out daily monitoring in the test area of the Bio-transplantation method.

\section{References}

1. F.D. Hukom, Prosiding Seminar Nasional Ikan, 4 (2010) 
2. J.H. Choat, D.R. Bellwood, In the ecology of fishes on coral reefs (Academic Press, San Diego, 1991)

3. T.A. Hadi, M. Abrar, Giyanto, B. Prayudha, O. Johan, A. Budiyanto, A. R. Dzumalek, L.O. Alifatri, S. Sulha, Suharsono, The status of Indonesian coral reef (Research Center for Oceanography, Cibinong, 2019)

4. J. Edwards, E.D. Gomez, Reef restoration concepts and guidelines: making sensible management choices in the face of uncertainty (Coral Reef Targeted Research \& Capacity Building for Management Programme, St Lucia, 2007)

5. J.D. Bell, R. Galzin, Mar. Ecol. Prog. Ser., 1 (1984)

6. Y.M. Bozec, S. Dolédec, M. Kulbicki, J. Fish Biol. 66, 4 (2005)

7. M. Adrim, M. Hutomo, J. Sea Res. 23, 2 (1989)

8. Mujiyanto, Bio-Transplants for Fisheries Enhancement, trobosaqua.com (2020)

9. S. English, C. Wilkinson, V. Baker, Survey manual for Tropical Marine Resources. 2nd edition, (Australian Institute of Marine Science, Townsville, 1997)

10. G. Prato, P. Thiriet, A. Di Franco, P. Francour, PLoS One 12 (2017)

11. H. Masuda, K. Amaoka, C. Araga, T. Uyano, T. Yoshino, The fishes of the Japan Archipelago $2^{\text {nd }}$ (University Press, Tokyo, 1984)

12. R. H. Kuiter, Tropical reef-fishes of the western pacific Indonesia and adjacent waters (Gramedia Pustaka Utama, Jakarta, 1992)

13. E. Lieske, R. Myers, Reef fishes of the world (Periplus Edition, Singapura, 1997)

14. G.R. Allen, R. Steene, P. Human, N. Deloach, Fish reef identifiication: Tropical Pasific (Standard Industries Pte Ltd. Singapore, 2003)

15. C.N. Bianchi, R. Pronzato, R. Cattaneo-Vietti, L. Benedetti Cecchi, Morri, C., P. Pansini, R. Chemello, M. Milazzo, S. Faschetti, A. Terlizzi, A. Peirano, E. Salvati, F. Benzoni, B. Calcinai, C. Cerrano, G. Bavestrello, Biol. Mar. Medit, 11 (2004)

16. E.E. Ampou, N. Widagti, S.C. Nugroho, I.M. Sangadji, J. Ecotrophic 14, 1 (2020)

17. U. Rustam, R. Aryawati, Isnaini, H. Surbakti, J. Kelaut. Tropis 22, 1 (2019)

18. S. Nastiti, Mujiyanto, Krismono, Jurnal Biologi Indones. 16, 1 (2020)

19. N. Edrus, T.A. Hadi, J. Lit. Perikan. Ind. 26, 2 (2020)

20. Estradivari, M. Syahrir, N. Susilo, S. Yusri, S. Timotius, Jakarta Coral Reefs: Longterm observation of the Thousand Islands coral reef (2004-2005) (Yayasan TERANGI, Jakarta, 2007)

21. R. Nggajo, Y. Wardiatno, N.P. Zamani, J. Ilmu-ilmu. Perairan. Perikan. Indones. 16, 2 (2009)

22. F. Tony, S. Soemarno, D.G.R. Wiadnya, L. Hakim, Biodiver. 21, 10 (2020).

23. U. Satapoomin, Raffles B. Zool. 48 (2000)

24. J. Du, K. Loh, W. Hu, X. Zheng, Y.A. Affendi, J.L.S. Ooi, Z. Ma, M. Rizman-Idid, A. A. Chan, J. Biodivers. Data 7 (2019)

25. M.J. Emslie, M. Logan, A. J. Cheal, Diversity, 11, 33 (2019)

26. R. Bawole, Postgraduate Thesis, Bogor (ID): IPB University (1998)

27. W.A. Nugraha, F. Mubarak, E. Husaini, H. Evendi, J. Ilm. Perikan. Kelaut. 12, 1 (2020) 


\section{Appendix}

Appendix 1. List of fish species at Bio Transplants area Tunda Islands Banten Province

\begin{tabular}{|c|c|c|c|c|c|c|}
\hline & Family & & Species & July 2019 & November 2019 & July 2020 \\
\hline \multirow[t]{4}{*}{1.} & Acanthuridae & 1. & Acanthurus leucopareis & & $\mathrm{x}$ & $\mathrm{Xxx}$ \\
\hline & & 2. & Ctenochaetus cyanochelus (juv.) & & & $\mathrm{xx}$ \\
\hline & & 3. & Neoglyphidodon carlsoni & $\mathrm{xx}$ & $\mathrm{xx}$ & \\
\hline & & 4. & Stegastes fasciolatus & & & $\mathrm{xx}$ \\
\hline \multirow[t]{5}{*}{2.} & Lutjanidae & 5. & Caesio cunning & & $\mathrm{xxx}$ & $\mathrm{xx}$ \\
\hline & & 6. & Caesio xanthonata & & $\mathrm{xxx}$ & $\mathrm{xxx}$ \\
\hline & & 7. & Caesio xanthonota & & & $\mathrm{xxx}$ \\
\hline & & 8. & Casio teres & & $\mathrm{x}$ & $\mathrm{xxx}$ \\
\hline & & 9. & Lutjanus ehrenbergii & & $\mathrm{xxx}$ & $\mathrm{xxx}$ \\
\hline \multirow[t]{8}{*}{3.} & Labridae & 10. & Chaerodon graphicus & & & $\mathrm{xxx}$ \\
\hline & & 11. & Chaerodon schoenleinii & & & $\mathrm{xxx}$ \\
\hline & & 12. & Cheilinus fasciatus & & & $\mathrm{x}$ \\
\hline & & 13. & Chlorurus troschelii & & $\mathrm{xxx}$ & $\mathrm{xx}$ \\
\hline & & 14. & Coris pictoides & & & $\mathrm{x}$ \\
\hline & & 15. & Halichoeres hortulanus & & & $\mathrm{x}$ \\
\hline & & 16. & Thalassoma amblycephalum & $\mathrm{xx}$ & & \\
\hline & & 17. & Thalassoma lunare & $\mathrm{xx}$ & $\mathrm{xx}$ & \\
\hline \multirow[t]{3}{*}{4.} & Serranidae & 18. & Cephalopholis polleni & & $\mathrm{xx}$ & $\mathrm{xxx}$ \\
\hline & & 19. & Epinephelus merra & & $\mathrm{xx}$ & $\mathrm{xxx}$ \\
\hline & & 20. & Epinephelus hexagonatus & & & $\mathrm{xx}$ \\
\hline \multirow[t]{4}{*}{5.} & Chaetodontidae & 21. & Heniochus chrysostomus & & & $\mathrm{xx}$ \\
\hline & & 22. & Chaetodon trifasciatus & & & $\mathrm{xx}$ \\
\hline & & 23. & Chelmon sp. & $\mathrm{x}$ & $\mathrm{x}$ & $\mathrm{xxx}$ \\
\hline & & 24. & Heniochus varius & $\mathrm{x}$ & $\mathrm{x}$ & $\mathrm{xxx}$ \\
\hline \multirow[t]{13}{*}{6.} & Pomacentridae & 25 . & Abudefduf sexfasciatus & & $\mathrm{xx}$ & $\mathrm{xxx}$ \\
\hline & & 26. & Abudefduf sordidus & & $\mathrm{x}$ & $\mathrm{xxx}$ \\
\hline & & 27. & Acanthochromis polyacanthus & & $\mathrm{xxx}$ & \\
\hline & & 28. & Acanthochromis polyacanthus & & $\mathrm{xx}$ & $\mathrm{xx}$ \\
\hline & & 29. & Amblygphidodon curacao & & & $\mathrm{Xxx}$ \\
\hline & & 30 . & Chromis artipes & & $\mathrm{x}$ & $\mathrm{xxx}$ \\
\hline & & 31. & Chromis fumea & & $\mathrm{xx}$ & \\
\hline & & 32. & Chromis viridis & & & $x x$ \\
\hline & & 33. & Chromis weberi & & & $\mathrm{x}$ \\
\hline & & 34. & Neoglyphidodon crossi & & & $\mathrm{xx}$ \\
\hline & & 35. & Neoglyphidodon melas & $\mathrm{xxx}$ & $\mathrm{x}$ & \\
\hline & & 36. & Neoglyphidodon migroris & & & $\mathrm{xx}$ \\
\hline & & 37. & Neopomacentrus azysron & & $\mathrm{x}$ & $\mathrm{x}$ \\
\hline
\end{tabular}




\begin{tabular}{|c|c|c|c|c|c|}
\hline \multicolumn{2}{|r|}{ Family } & Species & \multirow[t]{2}{*}{ July 2019} & \multirow[t]{2}{*}{ November 2019} & \multirow{2}{*}{$\begin{array}{c}\text { July } 2020 \\
\mathrm{XX}\end{array}$} \\
\hline & & 38. Pomacentrus alexandereae & & & \\
\hline & & 39. Pomacentrus chrysurus & & & $\mathrm{x}$ \\
\hline & & 40. Pomacentrus littoralis & & $\mathrm{x}$ & $x x$ \\
\hline & & 41. Pomacentrus moluccensis & $\mathrm{xxx}$ & & $\mathrm{x}$ \\
\hline & & 42. Pomacentus brachialis & $\mathrm{xxx}$ & $x x$ & \\
\hline & & 43. Pomachromis richardsonii & & & $\mathrm{x}$ \\
\hline & & 44. Stegastes lividus & & $\mathrm{xx}$ & $\mathrm{xxx}$ \\
\hline \multirow[t]{4}{*}{7.} & Scaridae & 45. Chlorurus sordidus & $\mathrm{xxx}$ & $\mathrm{XxX}$ & $\mathrm{XxX}$ \\
\hline & & 46. Scarus dimidiatus & & $\mathrm{xxx}$ & $\mathrm{XXX}$ \\
\hline & & 47. Scarus frenatus & & & $\mathrm{XxX}$ \\
\hline & & 48. Scarus frenatus & & $\mathrm{xx}$ & $\mathrm{x}$ \\
\hline \multirow[t]{4}{*}{8.} & Apogonidae & 49. Apogon anguttathus & $\mathrm{x}$ & & \\
\hline & & 50. Apogon cyanosoma & & $\mathrm{xxx}$ & $\mathrm{XXX}$ \\
\hline & & 51. Apogon endekataena & & $\mathrm{x}$ & $\mathrm{xxx}$ \\
\hline & & 52. Apogon fraenatus & & & $\mathrm{xxx}$ \\
\hline \multirow[t]{2}{*}{9.} & Blenniidae & 53. Aspedinantus taeniatus & $\mathrm{x}$ & & \\
\hline & & 54. Aspidontus fuscus & & $\mathrm{xxx}$ & $\mathrm{xxx}$ \\
\hline \multirow[t]{2}{*}{10.} & Nemipteridae & 55. Scolopsis bilineatus & & $\mathrm{xx}$ & $\mathrm{xxx}$ \\
\hline & & 56. Scolopsis lineatus & & $\mathrm{XXX}$ & $\mathrm{XXX}$ \\
\hline
\end{tabular}

Note: $\mathrm{x}=1-2$ individuals; $\mathrm{xx}=3-5$ individuals; $\mathrm{xxx}=>6$ individuals. 